\title{
Natural Resources Ecological Monitoring in Pirgulu State Nature Preserve
}

\author{
Ulviyya Mammadova
}

Department of Soils Agroecology and Bonitation, Institute of Soilscience and Agrochemistry of ANAS, Baki, AZ1073, Azerbaijan

\begin{abstract}
Appreciation of the innate resources in preserve serves biogeocenosis further protection concerning to woodland area. The major reserve is the solar energy potential to supply the energy demand of the population. Alternation of fuelwood into the renewable energy source is the ideal way of saving woodlands. That's why the total solar energy potential was determined in the region. Finally on the conclusions the solar energy potential map has been established.
\end{abstract}

Keywords Solar Energy, Energy Map, Innate Resource, Measurements

\section{Introduction}

While saying the natural resources of Pirgulu State Nature Preserve all biocenoses and biogeocenoses including characteristic landscape, soil cover are intended. The preserve surrounds the east border of woodland located on the south slope of the Great Caucasus mountain. In the scientific references natural resources of the region haven't been appreciated within the latest broadened borders [3,5] due to the demandable form. This' why natural resources determination in the territory and also study of the ecological status are important from scientific and practical facets in order to save historical areals. According to the ecological monitoring and researches realized in Pirgulu the innate reserves can be divided into different places. These're the soils cover, flora, fauna, relict and wealthy woodlands, solar, wind potentials and so on. Due to the objectives put forward on the research mainly ecological and economical investigation of soil cover, solar and wind energy potentials were fulfilled. After having enlarged the territory of the preserve soils' quantitative and qualitative assessment records intended in the state land cadastre were carried out by bonitation method[5,7] and the proper maps have been established. Almost solar and wind energy resources were firstly defined after long term measurement then the due to the result the energy potentials were ecologically estimated and mapped. These potentials validate the natural climatic condition. Three major natural resources of the preserve let the protection of phytocenosis, zoocenosis within the natural forest complexes. For forest safety having relict and wealthy soil securing facilities in several natural zone of the preserve

* Corresponding author:

ufsamadova@yahoo.com (Ulviyya Mammadova)

Published online at http://journal.sapub.org/ijee

Copyright (C) 2012 Scientific \& Academic Publishing. All Rights Reserved solar and wind energy potentials were determined. As the conclusion of the ecological monitoring in the settlements surrounding the woodlands instead of fuelwood these renewable energy sources application is profitable and advisable. In order to safeguard relict woodlands securing soil covers in each natural zone of the preserve the proposed way may be considered the most fruitful from ecological and economical facets $[3,7]$. The huge and initial energy source is solar. As the orig in energy basis of the processes happening in the biosphere average density of solar energy is 1,36 $\mathrm{kW} / \mathrm{m}^{2}$. By using only $0,01 \%$ of the falling

solar energy onto the Earth energy demand of whole the world can be provided. Distribution of solar energy regulation is characterized by changing in solar shining intensity during diurnal period on the seasons. Solar has great impact and importance in the innate activations within ecosystem. This importance is more than ever today when mankind is face to face with terrible ecological difficulties and energy crisis. During year amount of energy comes from solar to the Earth equals to $1500 \times 1012 \mathrm{~kW}$ [9]. Th is index is 150000 times more than the energy generated in the Planet at present. Only $0,2 \%$ of this energy is utilized for photosynthesis process of the flora in the Earth. As a rule solar energy the falls on to the Erath in visible light form $30 \%$ of the energy is absorbed and heats the surface, $70 \%$ of the energy rapidly reflects to the cosmos as ultra red rays. After become cold energy reflects in the form of visible light to the space. In this case infrared or hot rays separate from the Earth. As for the solar radiation due to forms the energy is divided to direct, diffuse and albedo solar radiations. Under the influence of solar[2,4] wind, wave, tide (ebb tide), heat gradient of the ocean, hydroenergy, energy obtained from photosynthesis process and so on happen. Depending on the falling of solar rays onto the Erath the waste gases in the atmosphere possessing long life leads to untraditional distributing or unreflecting the energy. Anomaly appearing 
in solar energy distribution makes changing in the climate at the result of this in the landscape, also in living organisms' development dynamics. Solar energy usage is widely used especially in four directions in the Earth. These're thermal-technical, photoelectric, biology and chemical fields. Because of the perspectives form power engineering facet solar energy is ecological clean and the most lucrative. But for the energy demand provision forests're hewed hugely order to get fuelwood which causes ruin of innate complexes. In the mountainous and foothill regions solar energy is enough for application to save woodlands. On the exploitation scope of the solar energy plants and equipment different solar radiations should be defined, that's why long term observations and measurements[7,10] have to be realized in the territory. To select the constructive and energy parameters rightly sunny, cloudy and without sunny hours in the investigation $[3,6,8]$ area are to be learnt for total solar radiation potentials calculation.

\section{Object and Methods of the Study}

Accordingly the territory of Pirgulu State Nature Preserve located on the southern-east slope of the Great Caucasus mountain is especially safeguarded as the innate resource complex. It should be mentioned that $70-80 \%[5,8]$ of the area was under the woodlands, now this index has been decreased more than once. The close touch on the settlements and villages leads to the current problems. While organizimg the investigations measurements year by year have been carried out for determing solar energy potential in the region. Taking into considration the height where the research area is situated, on the horizon in $800-2500 \mathrm{~m}$ imtervals the preserve territory i divided into three stations. In Jangi area in 800 - $1000 \mathrm{~m}$ above sea level, in Pirgulu area in $1500-2000 \mathrm{~m}$, in Arakhchin in $2000-2200 \mathrm{~m}$, observations and measurements have been imp lemented[10]. After realizing these works for defining the mount of the total radiation quantity of the sunny days are certainly to be known. The none sunny[1] days are the sum of the days without sun entirely. So on the hot and cold periods of the year annual amount of none sunny days in Pirgulu State Nature Preserve was defined and tabled.

As seen from the table 4.1. amount of the sunny non days for warm period is averagely 15 , for cold period 44,4 . along the year average non sunny days are 60,4 . In order to investigate the necessary solar radiations, sunny days total amount has to be exacted on the research objectives. By this purpose due to the seasons, cold and warm periods of the year and annual sunshine hour quantity was determined, then given at the following table.

As seen from table 4.2. average quantity of sunshine hours consists of 2088 hour/year. The difference between cold (October-March - 776 hours) and warm (April-September months -1308 hours) periods reaches to twice on a par. In the mean in winter months the lowest and in summer months the highest indicates are observed. Including the monitoring and measurements in the investigation area, depending on the height horizon in all three stations of the region sunshine amount was defined at the result of the observations. Sunshine hours are closely connected with the region's orography, cloudiness character and properties, air circulations features. That's why annual, subannual and seasonal distribution amount of sunshine hours is various. In revealing solar energy potential determination of the cloudy days in the territory is one of the major para meters. During the monitoring and surveillances on the base of the investigation and gauging quantity of the cloudy days was learnt. The annual and the seasonal conclusions were given at the table below (with\%).

Table 1. Nonsunny-days of the T erritory of Pirgulu State Nat ural Preserve

\begin{tabular}{|c|c|c|c|c|c|c|c|c|}
\hline \multirow{2}{*}{\multicolumn{2}{|c|}{ Heigh t( $)$}} & \multicolumn{7}{|c|}{ Te rritory of Pirgulu State Natu ral Preserve, (days) } \\
\hline & & \multirow{2}{*}{$\begin{array}{c}\text { spring } \\
16 \\
\end{array}$} & \multirow{2}{*}{$\begin{array}{c}\text { summer } \\
2 \\
\end{array}$} & \multirow{2}{*}{$\begin{array}{c}\text { autumn } \\
17 \\
\end{array}$} & \multirow{2}{*}{$\begin{array}{c}\text { winte } \mathbf{r} \\
28 \\
\end{array}$} & \multirow{2}{*}{$\frac{(\text { Apr./Sept. })}{13}$} & \multirow{2}{*}{$\begin{array}{c}\text { (Oct.Mar.) } \\
50\end{array}$} & \multirow{2}{*}{$\begin{array}{c}\text { Annual } \\
63 \\
\end{array}$} \\
\hline \multirow{5}{*}{ 吾 } & 800 & & & & & & & \\
\hline & 1000 & 17 & 3 & 18 & 23 & 16 & 44 & 61 \\
\hline & 1500 & 17 & 4 & 18 & 21 & 17 & 43 & 60 \\
\hline & 2000 & 16 & 5 & 17 & 21 & 16 & 43 & 59 \\
\hline & 2500 & 15 & 6 & 14 & 20 & 13 & 42 & 55 \\
\hline \multicolumn{2}{|c|}{ Ave rage: } & 16,2 & 4 & 16,8 & 22,6 & 15 & 44,4 & 59,6 \\
\hline
\end{tabular}

Table 2. Sunshine hour amount in Pirgulu State Nature Preserve

\begin{tabular}{|c|c|c|c|c|c|c|c|c|}
\hline \multirow{2}{*}{\multicolumn{2}{|c|}{ height (m) }} & \multicolumn{7}{|c|}{ Territory of Pirgulu State Natu re Prese rve, (hour) } \\
\hline & & \multirow{2}{*}{$\begin{array}{c}\text { spring } \\
540 \\
\end{array}$} & \multirow{2}{*}{$\begin{array}{c}\text { summer } \\
840 \\
\end{array}$} & \multirow{2}{*}{$\begin{array}{c}\text { au tumn } \\
500 \\
\end{array}$} & \multirow{2}{*}{$\begin{array}{c}\text { winte r } \\
320 \\
\end{array}$} & \multirow{2}{*}{$\begin{array}{c}(\text { Apr./Sept. }) \\
1460\end{array}$} & \multirow{2}{*}{$\begin{array}{c}\text { (Oct./Mar.) } \\
760\end{array}$} & \multirow{2}{*}{$\begin{array}{c}\text { Annual } \\
2200 \\
\end{array}$} \\
\hline \multirow{5}{*}{ 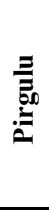 } & 800 & & & & & & & \\
\hline & 1000 & 500 & 780 & 500 & 350 & 1370 & 760 & 2130 \\
\hline & 1500 & 480 & 730 & 480 & 390 & 1270 & 800 & 2080 \\
\hline & 2000 & 490 & 720 & 450 & 370 & 1200 & 800 & 2030 \\
\hline & 2500 & 540 & 690 & 440 & 330 & 1240 & 760 & 2000 \\
\hline \multicolumn{2}{|c|}{ Ave rage: } & 510 & 752 & 474 & 352 & 1308 & 776 & 2088 \\
\hline
\end{tabular}


Table 3. Cloudy days' amount in Pirgulu State Nature Preserve

\begin{tabular}{|c|c|c|c|c|c|c|c|c|}
\hline \multirow{2}{*}{\multicolumn{2}{|c|}{ Height (m) }} & \multicolumn{7}{|c|}{ Territ ory of P irgulu State Nature Preserve, with \% } \\
\hline & & spring & summer & autumn & winter & (Apr./Sept.) & (Oct.Mar.) & Annual \\
\hline \multirow{5}{*}{$\begin{array}{l}\overrightarrow{\vec{B}} \\
\stackrel{\overrightarrow{E_{0}}}{\vec{B}}\end{array}$} & 800 & 6,9 & 4,8 & 6,0 & 6,8 & 6,0 & 6,7 & 6,0 \\
\hline & 1000 & 7,2 & 5,3 & 6,2 & 6,6 & 6,1 & 6,8 & 6,3 \\
\hline & 1500 & 7,4 & 5,7 & 6,2 & 6,2 & 6,4 & 6,4 & 6,4 \\
\hline & 2000 & 7,4 & 5,9 & 6,2 & 5,7 & 6,5 & 5,8 & 6,4 \\
\hline & 2500 & 7,3 & 6,1 & 6,0 & 5,5 & $\overline{6,6}$ & $\overline{5,6}$ & 6,3 \\
\hline \multicolumn{2}{|c|}{ average: } & 7,24 & 5,56 & 6,12 & 6,16 & 6,32 & 6,26 & 6,28 \\
\hline
\end{tabular}

Table 4. Total solar radiation amount in Pirgulu State Nature Preserve

\begin{tabular}{|c|c|c|c|c|c|c|c|c|}
\hline \multirow{2}{*}{\multicolumn{2}{|c|}{ Height(m) }} & \multicolumn{7}{|c|}{ Territory of Pirgulu State Nature Preserve, $\left(\mathrm{kcal} / \mathrm{cm}^{2}\right)$} \\
\hline & & sping & summer & autumn & winter & (Apr./Sept.) & (Oct.Mar.) & Annual \\
\hline \multirow{5}{*}{$\begin{array}{l}\vec{\exists} \\
\overrightarrow{\sigma_{0}} \\
\stackrel{\overrightarrow{0}}{*}\end{array}$} & 800 & 32,8 & 47,4 & 25,2 & 15,0 & 83,0 & 37,8 & 121,0 \\
\hline & 1000 & 33,8 & 47,8 & 25,9 & 16,2 & 83,5 & 39,5 & 124,5 \\
\hline & 1500 & 35,8 & 48,6 & 27,2 & 17,6 & 85.5 & $\overline{42,0}$ & 129,0 \\
\hline & 2000 & 37,7 & $\overline{49,4}$ & 28,5 & 19,1 & $\overline{88,0}$ & 44,5 & 133,0 \\
\hline & 2500 & 39,6 & $\overline{50,2}$ & 29,8 & 20,5 & $\overline{90,0}$ & $\overline{47,3}$ & 137,5 \\
\hline \multicolumn{2}{|c|}{ average: } & 35,94 & 48,68 & 27,32 & 17,68 & 68,9 & 42,22 & 129 \\
\hline
\end{tabular}

As seen from the table 4.3. after having oversighted the coudy days quantity, it was revealed that along year average index changes between $6-6,28$ days. Also the very index is characteristic because of the little difference in both cold and warm periods of the year. On the seasons only in summer months $(5,56 \%)$ cloudy days is less. In winter season such days cocnsists of $6,16 \%$ by little inequality with autumn. The highest indicate comes from the region climate possibilities happens in spribg months. The energy plants intende to apply in the investigation area work with diffuse and direct solar radiations. Measurements and monitoring have been directed to determine these radiations' quantity. By utilizing spesific methodes, according to the hundred yearly data of the weather stations and the current own measurements the total rediation potention of the territory has been calculated on the formula.

$$
(Q+q)_{n}^{\prime}=(Q+q)_{0}[1-(1-k) n]
$$

$(Q+q)_{n}^{\prime}-$ in real condition total solar radiation of the cloudiness $\left(\mathrm{kcal} / \mathrm{cm}^{2}\right) ; n$-daily (at 7,13,19o 'clock) average monthly amount of the total cloudiness with exactness $\frac{1}{10}$ part of unit; $(Q+q)_{0}$ - total solar radiation in cloudless hours of the sky; $k$ - coefficient showing the total solar radiation reaching to the earth from the higher layers of the cloudiness; $k$ and $(Q+q)_{0}$ marks are determined from the working tables established by T. G. Berlyand.

On the middle and higher mountainous zone annual showings of the total solar radiation is revealed by their gradients. The annual quantity for plains, low mountainous and mountainous zones the following formu la was used:

$$
(Q+q)_{n}^{i}=0,98(Q+q)_{n}^{\prime}+7,2
$$

This gradient on the southern-east slope of the Great Caucasus is $0,8 \mathrm{kcal} / \mathrm{cm}^{2}$ per each $100 \mathrm{~m}$ height in $1 \mathrm{~cm}^{2}$. That's expressed as (Grad)year $=0,8 \mathrm{kcal} / \mathrm{cm}^{2}$ for $100 \mathrm{~m}$.

Beginning from $800(600) \mathrm{m}$ above sea level, monthly coefficients are built on annual process of the total radiation expressed by $\%$. The given gradient coefficient depends on relief, distribution of sunshine, regime of cloudiness and precipitations. This's why on the southern-east slope of the Great Caucasus gradient coefficient is considered 1,2 $\mathrm{kcal} / \mathrm{cm}^{2}$ per $100 \mathrm{~m}$ height. During a year a mount of total solar radiation (due to direct and diffuse solar radiations) on the seasons was tabled and given at the below.

As seen from the table the higher annual mark of the total radiation is $137,5 \mathrm{kcal} / \mathrm{cm}^{2}$, at $2000-2005 \mathrm{~m}$ above sea level in Arakhchin area. But on whole natural zone average annual mark of the direct solar rad iation is $129 \mathrm{kca} 1 / \mathrm{cm}^{2}$.

On the southern slopes absorption ability of solar radiations is higher in these areas forest-plant formations are able to develop perfectly. On the slopes forest formatting trees with large leaves, relict and wealthy plant species are frequently met. Because the trees with large leaves and thick leafage absorb the solar energy more for realizing photosynthesis process, inclination and view feasibilities of the slopes make solar energy application be possible in the region.

On the northern slopes phytocenosis development is a bit weak and on separate slopes within the forest belt contents there's difference in vegetation, blossoming, fruiting durations of the plant formation. Here mostly trees and bushes with acerose leaf or little trees (bushes) with thin leafage are often observed. The climate formatting this distinction bases on the solar radiation distribution depending on relief factor. Due to the dimension results of direct and diffuse radiation, calculating and processing the data, then total solar radiation of the preserve was exacted. After having analyzed the scientific referenced sited it was revealed that the there's little research works on solar energy potential determination in the Republic. Up today from energy point of view solar energy potential of the Republic wasn't estimated and validated.

Generally solar radiation is permanent energy source for all the innate processes happening in the atmosphere, hydrosphere, lithosphere (upper layer) and biosphere. In human life and activation field, especially in the agriculture solar energy has great importance. 


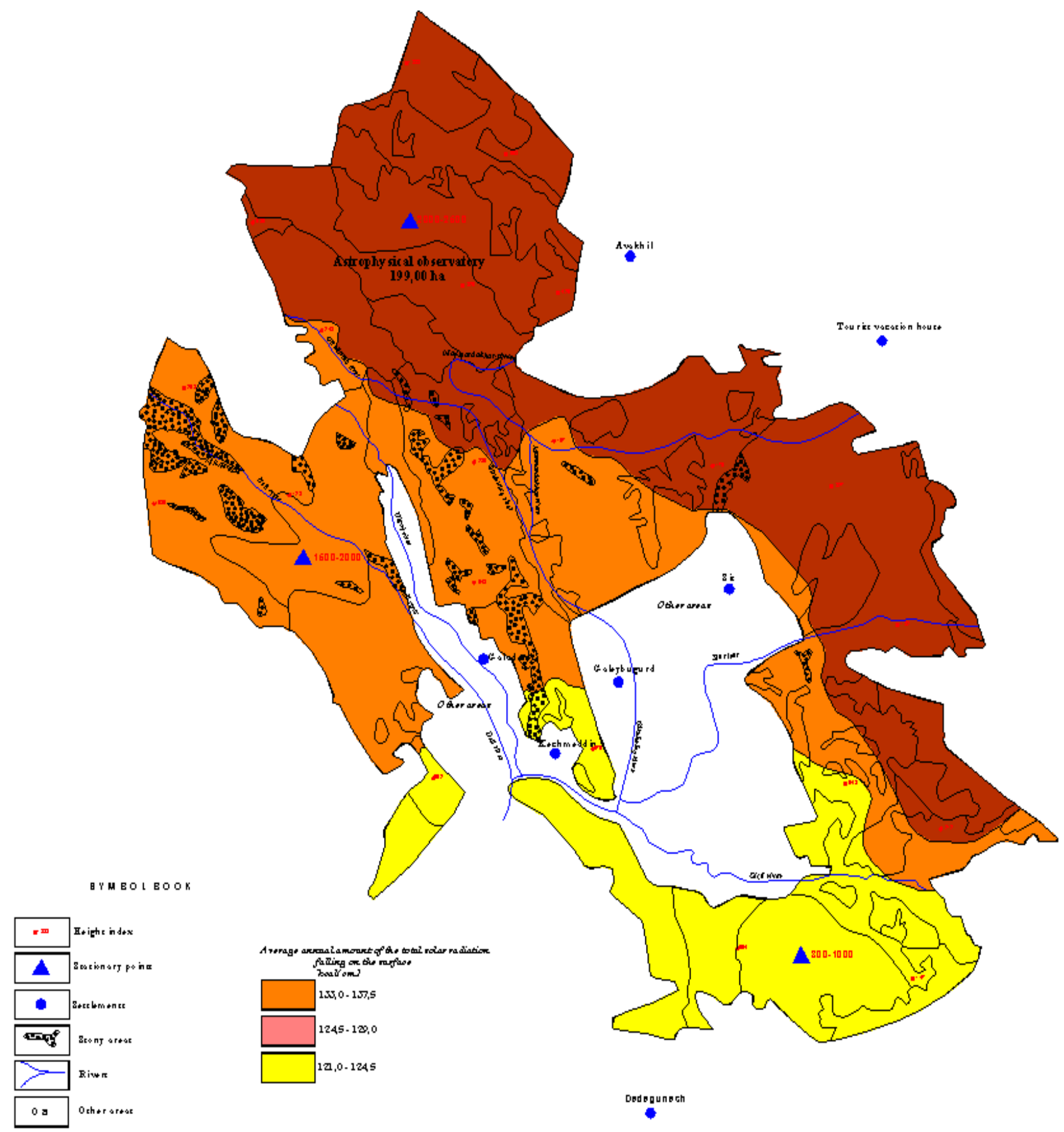

Figure 1. Annual total solar energy potential in Pirgulu State NaturalPreserve of Azerbaijanon 1:25000 scale

Finally after the investigation carried out annual solar energy potential of Pirgulu State Nature Preserve (Arakhchin, Pirgulu and Jangi) has been mapped. Almost heat balance in some regions of the Great Caucasus natural zone have been revealed at the result of realized investigations and due to the long term data given from the weather stations in 1960s years.

From the map it's clear that on three natural zone annual total solar energy potential changes between 137,5-124,5 $\mathrm{kcal} / \mathrm{cm}^{2}$ interval. Taking into account the relief forms and height from the sea level high, medium and low solar energy potentials exist in the preserve. For climatic forcast purpose solar energy out and income have partly learnt. The scope of such investigations was agroclimate probabilities processing for developing and improving several branches and level of agriculture.

\section{Results and Discussions}

Today in majority of the world countries mobile and stationary actinometrical complexes put on high 
mountainous and foothill areas possesses essential relevance in solar energy potential study. Installation of the modern actinometrical complexes in the Republic is delaying yet. According to the vertical zonality regulation realization of the measurements some difficulties appear. On the height from the sea level and relief and solar energy distribution of the natural zone biodiversity development is distinguished. This potential gives opportunity to save woodlands extended on the southern-east slope of the Great Caucasus mountain and supply energy demand of the population living surrounding the woodland areas. It should be noticed that study and application of solar energy potential in the region can lead several purposes. Within the same regulation amount of the weather stations located in different heights validate this. Depending on the height location points of the weather stations are divide into four groups:

In $<500 \mathrm{~m}$ above sea level- 47 meteorological stations;

In 500-1000 $\mathrm{m}$ above sea level- 15 meteorological stations;

In 1000-2000 $\mathrm{m}$ above sea level- 15 meteorological stations:

In $2000 \mathrm{~m}$ above sea level -8 meteorological stations;

In $3000 \mathrm{~m}$ above sea level - 1 new meteorolog ical station.

All the measurements of the existing weather stations for a long time have been analy zed only for the above mentioned goals. Study of solar energy potential was carried out for meteorological aim, all calculations concerned to this. In order to use alternative energy sources the results can be used. Because beside the existing energy sector to organize alternative and renewable energy sectors is possible after solar energy potential determination. The revealed potential may be the basis of new direction for developing "Solar power engineering». Lately the works are being realized for this aim. For application in some technological process solar energy potential of Absheron peninsular was learnt. To the scope of the research done solar energy potential determination in Pirgulu State Nature Preserve consists of solar energy utilization in individual houses, enterprises and other buildings for preventing some processes and solving the current ecological problems standing in agenda. For protection of Pirgulu forests being hewed the total solar energy potential working is the major factor to realize calculations on technical, constructive and energy parameters of the plants in solar energy usage provision. Annual and seasonal indexes determination in the areas having the highest potentials validate effective utilization of solar energy.

\section{Conclusions}

According to the calculations implemented on the base of the long term investigations fulfilled in 800-2500 m height above sea level in the investigation territory, the following results have been come into conclusion:

- Average annual amount of non sunny days 60-61 days, in April-September period the average index 15 days, in
October-March period 44-45 days;

- Average annual a mount of sunshine hours 2094 hours, in April-September period the average index 1308 hours, in October-March period 776 hours;

- The level of the cloudiness average annual $6,28 \%$, in April-September period the average index $6,32 \%$, in October-March period 6,26\%;

- Average annual total solar radiation $129 \mathrm{kcal} / \mathrm{cm}^{2}, \%$, in April-September period the average index $68,9 \mathrm{kcal} / \mathrm{cm}^{2}$, in October-March period 42,22 $\mathrm{kcal} / \mathrm{cm}^{2}$.

From the conclusion it is clear that solar energy potential of the region gives opportunity to use solar energy resources widely in individual and combined form in the villages surrounding Pirgulu State Nature Preserve for woodlands safety.

\section{REFERENCES}

[1] Mammadov F.F., Samadova U.F., Huseynov G.M. Solar Power Engineering Terms Dictionary (in seven languages Azerbaijan, Russian, English, German, French, Ispanish, Italian). Baki: «Elm» 2009, 360 p.

[2] Mammadov G.Sh. Mammadova (Samadova) U.F., Mammadov F.F. Economical Calculation of Fire-woods' Hewing Damages from the Forests. Collection of Soiscience and Agrochemistry. XIX vol. 2011, pp. 283-288.

[3] Mammadov G.Sh., Samadova U.F., Mammadov F.F. Solar Energy Potential of the Southern-East Slope of the Great Caucasus. News Journal of ANAS Ganja Regional Scientific Center. № 39, 2010, pp 46-50.

[4] Mammadov G.Sh., Samadova U.F., Mammadov F.F. Ways of Environmental Protection of The Forest Soil Covers. Collected Works of Azerbaijan Soil Scientists Society. XIX vol. I part. 2009, pp. 539-541.

[5] Mammadov G.Sh., Samadova U.F., Mammadov F.F. Ecological Protection of the Woodlands. Reports of ANAS LXV vol, № 6. 2009, pp. 115-118.

[6] Mammadova (Samadova) U.F. Open Bonitation Scale of Forest and Woodless Soils in Pirgulu State Nature Preserve. Soilscience and Agrochemistry Journal XX vol, № 1. 2011, pp. 613-618.

[7] Mammadova U.F. Ecological Estimation of Forest soils in Azerbaijan. Journal of Ecology and The Natural Environment № 6, vol. 3. 2011, pp. 181-185.

[8] Mammadova U.F. Soil Study of Woodland in Pirgulu State Nature Preserve of Azerbaijan. World Environment Journal № 2, vol. 1. 2012, pp. 41-45.

[9] Mammadova U.F. Study of Azerbaijan Forests' Ecological State. Conference Material on Improvement of Agrarian Science by Solving Food Safety Provision Problems. Guba: 2011, 14-16 May, pp. 381-389.

[10] Samadova U.F. Solar and Wind Energy Application for the Woods and Forest Soil' s Protection // Renewable Energy Congress X, Glasgow, Scotland, 19-25 July 2008, pp $512-514$. 